\title{
Seasonal and interannual variability in larval lobster Homarus americanus size, growth and condition in the Magdalen Islands, southern Gulf of St. Lawrence
}

\author{
Patrick Ouellet* ${ }^{*}$ Jean-Pierre Allard
}

Fisheries and Oceans Canada, Maurice Lamontagne Institute, 850 route de la mer, Mont-Joli, Québec G5H 3Z4, Canada

\begin{abstract}
Seasonal and interannual patterns in lobster larvae and post-larval stage size (mean carapace length: CL), percent size increase at molt, growth rates $\left(\mathrm{mg}\right.$ protein $\left.\mathrm{d}^{-1}\right)$, and nutritional condition (TAG/sterol and TAG/total protein ratios; TAG: triacylglycerols) are presented for the lobster population at the Magdalen Islands, southern Gulf of St. Lawrence (Canada) for 3 yr (1996 to 1998). The effects of water temperature on stage duration and larval protein growth rates seem to determine the seasonal pattern of variability in size of lobster larvae. Stage I larvae CL showed no seasonal decline each year, but diminishing size increases at the first molt following the warming of the water column were apparently responsible for declining stage II and III larvae CL. Under warmer and more stable water temperature conditions in mid-summer (August), higher protein growth rates during the third larval stage compensated for inverse temperature effects on post-larvae size; as a consequence, the seasonal declines in post-larvae CL were not significant except during 1998, when water temperature in late August was colder. The lipid-based condition indices suggest that seasonal larval growth was not affected by changes in food availability in any year of the study. Lobster postlarvae can vary by up to 10 and $20 \%$ in CL and biomass (total protein), respectively, within a season. It would appear that the great range in size at age reported in lobsters might originate during the conditions for growth and development of the larval stages.
\end{abstract}

KEY WORDS: Lobster · Larvae $\cdot$ Post-larvae $\cdot$ Lipid condition $\cdot$ Molt increment $\cdot$ Protein growth rate $\cdot$ Temperature Resale or republication not permitted without written consent of the publisher

\section{INTRODUCTION}

Development and growth rates of the larval stages determine timing and size at metamorphosis (i.e. postlarvae size) and influence settlement success and juvenile growth in American lobster Homarus americanus (James-Pirri et al. 1998). In addition, post-larvae size can vary significantly within an area, and early postlarvae are usually larger than late season post-larvae (Hudon \& Fradette 1988, James-Pirri et al. 1998). How-

*E-mail: ouelletp@dfo-mpo.gc.ca ever, although temperature is thought to play an important role in determining development rate and perhaps size of lobster larvae (Templeman 1936, 1948, Hudon \& Fradette 1988, MacKenzie 1988, Ennis 1995), the factors that determine the amplitude of intra- and interannual variability in larvae and post-larval stage sizes are not well understood. For example, it is unclear how the initial size and growth rate of the planktonic larval stages determine the characteristics of lobster post-larvae.

As part of an integrated research program on lobster ecology, biology, population dynamics and fisheries in Atlantic Canada, the larval population at the Mag-

(C) Inter-Research $2002 \cdot$ www.int-res.com 


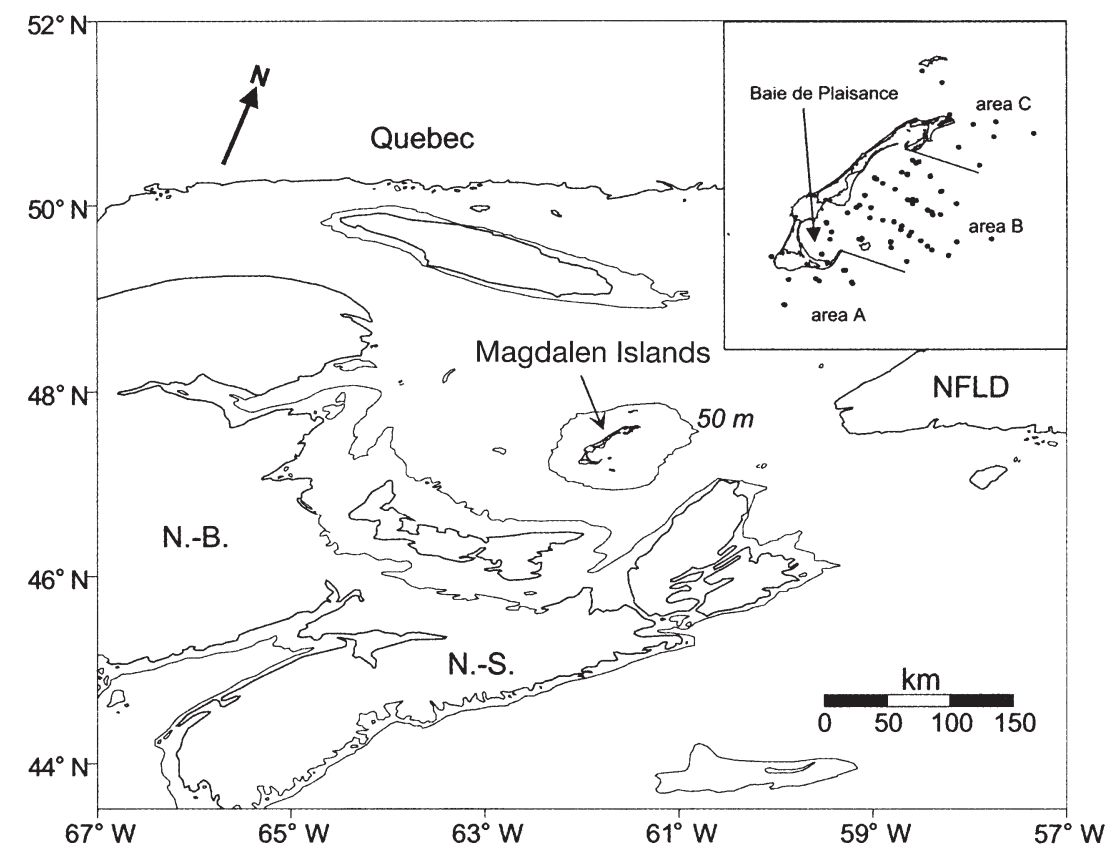

Fig. 1. Location of the Magdalen Islands in the southern Gulf of St. Lawrence. The insert illustrates a typical distribution of the sampling stations (black dots), on lines perpendicular to the east coast, for the July surveys and the subdivision of the survey area for the analysis. For the August/September post-larvae surveys, the sampling was concentrated in the southern half of area B and Baie de

Plaisance. N.-B.: New Brunswick; N.-S.: Nova Scotia; NFLD: Newfoundland

(Hudon at al. 1986, Ouellet et al. 2001). Lobster planktonic post-larvae are found from the end of July to September with maximum abundance recorded in early August (Ouellet et al. 2001). In this paper, discrete growth as percent size increase at the molt, mean growth rate $\left(\mathrm{mg}\right.$ protein $\mathrm{d}^{-1}$ ) and nutritional condition of lobster larval stages are presented for the Magdalen Islands population. Our objectives are to describe the patterns of seasonal and interannual variability in larvae size and to determine if differences in larval size and growth rates can explain differences in lobster post-larvae size (i.e. size at settlement).

\section{MATERIALS AND METHODS}

Sampling of lobster planktonic stages. A summary of the lobster larvae sampling program from 1996 to 1998 is presented in Table 1. A largescale survey was carried out in July, the period of maximum larvae production, of each year. Past studies have shown that lobster larvae in the south-

dalen Islands was studied for $3 \mathrm{yr}$ (1996 to 1998) to investigate the processes involved in determining young-of-the-year abundance and recruitment success. The Magdalen Islands are a small group of 7 islands occupying a shallow area $(<50 \mathrm{~m})$ in the southern Gulf of St. Lawrence (see Fig. 1). The local lobster population is considered isolated from other populations in the southern Gulf by (1) the deep cold water surrounding the archipelago, which prevents adult lobster migration, and (2) the surface circulation features which are favorable to larval retention (Hudon et al. 1986). If indeed the lobster population around the Magdalen Islands is largely 'self-sustained', then it would represent an ideal case to study the relationship between egg production and recruitment within a population. In addition, investigation of the condition and growth of the larval stages can provide insight into the ecological and biological processes that determine recruitment level to the population.

Lobster Stage I larvae appear in the plankton around the Magdalen Islands at the end of June/early July and mean concentrations peak in the second and third week of July (Hudon et al. 1986, Ouellet et al. 2001). Stage I larval production lasts until the end of August/ early September but the mean concentrations are much smaller late in the season compared to early July ern Gulf of St. Lawrence are concentrated near the surface of the water column (Scarratt 1973, Hudon et al. 1986). Two $1 \mathrm{~m}^{2}(1 \times 1 \mathrm{~m})$ nets mounted one over the other (i.e. sampling between 0 and $1 \mathrm{~m}$ and between 1 and $2 \mathrm{~m}$ simultaneously) were fixed below the midsection of the bow bridge of a SWATH (small waterplane area twin hull) ship, the FG 'Creed', allowing sampling of the undisturbed first $2 \mathrm{~m}$ of the water column with great efficiency. Each net frame was equipped with $1 \mathrm{~mm}$ mesh net and General Oceanic flowmeters. Stations were located generally on lines perpendicular to the Islands coast, and each tow, beginning at the selected location on a line, was carried out with the ship moving forward (i.e. pushing the nets) at 3 to 4 knots facing the waves or the predominant wind. Each tow lasted 30 min for a displacement of about $2 \mathrm{~km}$ on average. In addition to the July surveys from the first week of July to the second week of September, we conducted surveys in the southeast region (Baie de Plaisance) to investigate the abundance and distribution of lobster post-larvae yearly (Table 1). Lobster post-larvae are almost exclusively caught at the surface (Harding et al. 1987). Two rectangular nets $(1 \times 0.5 \mathrm{~m})$ attached side by side (i.e. a $2 \times$ $0.5 \mathrm{~m}$ total opening area) were mounted on an articulated aluminum arm on the bow of a small Boston 
Whaler type vessel. Sampling was carried out 3 to 4 times per week, or more when the meteorological conditions were good, for the entire sampling season. With each plankton tow during each survey, a temperature profile of the water column was recorded with a SeaBird CTD probe. The data were used to calculate mean water temperature for the surface mixed layer (either from the surface to the bottom or from the surface to the thermocline depending on the depth at the station) of the water column; which represents the thermal habitat of the developing lobster larvae.

A comparison of the data from the upper $1 \mathrm{~m}^{2}(0$ to $1 \mathrm{~m}$ ) net and the rectangular nets during simultaneous sampling in July 1996 showed that both gears were equally efficient in sampling lobster planktonic stages. Therefore, by combining 2 or 3 surveys each year, we were able to have complete seasonal coverage of lobster larvae and post-larvae abundance in the eastern region of the Magdalen Islands (see Fig. 1).

For each survey at each station, the plankton samples were examined for the presence of lobster larvae and post-larvae. When the larvae were present in relatively high abundance, a subsample (up to 5 specimens per stage) was sorted and preserved in liquid nitrogen for biochemical analyses (lipid and protein content). The rest of the sample was preserved in a seawater/ formaldehyde (96:4 v/v) solution. Subsequently, in the laboratory, all larvae from the formaldehyde preserved sample were sorted, staged, and measured (carapace length: CL) with an image digitizer system (BIOQUANT $^{\mathrm{TM}}$ system IV, R \& M Biometrics). The CL was measured from the rear of the eye socket to the back of the carapace following a line parallel to the medio-dorsal plane (Hudon \& Fradette 1988).

Biochemical analyses. Total protein: Individual larvae were taken from liquid nitrogen storage and allowed to thaw on crushed ice for the extraction of the hepatopancreas gland for lipid determination (see below). Total protein content (i.e. live biomass) was then determined on the larva without the digestive gland with the bicinchoninic acid assay kit (TPRO-582, Sigma Aldrich). During an earlier experiment, the hepatopancreas wet weight was estimated to account for ca. $20 \%$ of total wet weight in lobster post-larvae and early (instars $\mathrm{V}$ and VI) juveniles (P. Ouellet unpubl. data). Individual larvae were homogenized in $0.05 \mathrm{M}$ Tris/0.1 M NaCl $(\mathrm{pH}$ 8.0) for protein determination. A $250 \mu \mathrm{l}$ aliquot of the homogenate was transferred into a clean tube where the protein were extracted from the homogenate in a $10 \mathrm{M}$ urea glacial acetic acid solution $(29: 1 \mathrm{v} / \mathrm{v})$ for $30 \mathrm{~min}$
(Somero \& Childress 1990). Following extraction, total protein was assayed in triplicate according to the procedure described with the Sigma bicinchoninic acid assay kit.

Hepatopancreas lipids: The hepatopancreas was isolated by removing the cephalothorax carapace and returning the larvae to a small (13 mm diameter) glassfiber filter paper (previously rinsed with acetone) that absorbed the hepatopancreas. The filter paper was placed in a $1.5 \mathrm{ml}$ cryoviale with dichloromethane $(\mathrm{DCM}) / \mathrm{methanol}(\mathrm{MeOH})(2: 1 \mathrm{v} / \mathrm{v})$ solution and stored at $-80^{\circ} \mathrm{C}$ in preparation for the lipid analysis. Neutral lipids, including the triacylglycerols (TAG), are extruded from the tissue almost instantly in the $\mathrm{DCM} / \mathrm{MeOH}$ solution; nevertheless, after removing it from the low-temperature freezer, the cryoviale was allowed to stay at room temperature for at least $12 \mathrm{~h}$ before proceeding with lipid analysis on the Iatroscan. First, a known amount of nonadecane was added to the solvent and lipid solution as an internal standard for lipid quantification. The lipid solution was removed in totality from the cryoviale and transferred to a clean borosilicate tube. The following steps for the concentration of the lipid sample and for the sequential development and quantification on chromarods with the Iatroscan are described in protocols presented by Ouellet et al. (1992) and Harding \& Fraser (1999).

Estimation of growth rates from field samples and statistical methods. The estimated duration of each larval stage was determined from the daily mean surface water temperature using the relationships proposed by MacKenzie (1988). For the period of the surveys, the stage-duration estimates varied from 5 to $8 \mathrm{~d}$ (Stage I), 5 to $10 \mathrm{~d}$ (Stage II), and 6 to $10 \mathrm{~d}$ (Stage III) for all years. Therefore, the sampling seasons were divided into sampling weeks; i.e. in $6 \mathrm{~d}$ periods from Monday to Saturday, and the estimation of weekly mean growth rates were made by the comparison of the mean characteristics CL, TAG, total protein, etc.) of successive stages on successive sampling weeks. For example,

Table 1. Sampling schedule at the Magdalen Islands during the period from 1996 to 1998 and sampling effort per zone for each cruise. BW: 'Boston Whaler' type vessel $(8 \mathrm{~m})$

\begin{tabular}{|clllrrr|}
\hline \multirow{2}{*}{ Year } & \multirow{2}{*}{ Cruise } & \multirow{2}{*}{ Date } & \multicolumn{2}{c}{ Type } & \multicolumn{3}{c|}{ No. of tows (Area) } \\
& & & & A & B & C \\
\hline 1996 & Creed & 13-21 Jul & Surface $(0-2 \mathrm{~m})$ & & 31 & 8 \\
& BW & 28 Jun-11 Sep & Neuston $(0-0.5 \mathrm{~m})$ & & 187 & \\
1997 & Navicula & 2-23 Jul & Surface $(0-1 \mathrm{~m})$ & 9 & 54 & 9 \\
& Creed & 1-12 Aug & Surface $(0-2 \mathrm{~m})$ & & 31 & 14 \\
& BW & 22 Jul-4 Sep & Neuston (0-0.5 m) & 57 & \\
1998 & Creed & 11-22 Jul & Surface $(0-2 \mathrm{~m})$ & 18 & 36 & 5 \\
& BW & 6 Jul-11 Sep & Neuston $(0-0.5 \mathrm{~m})$ & & 153 & \\
& & & & & & \\
\hline
\end{tabular}




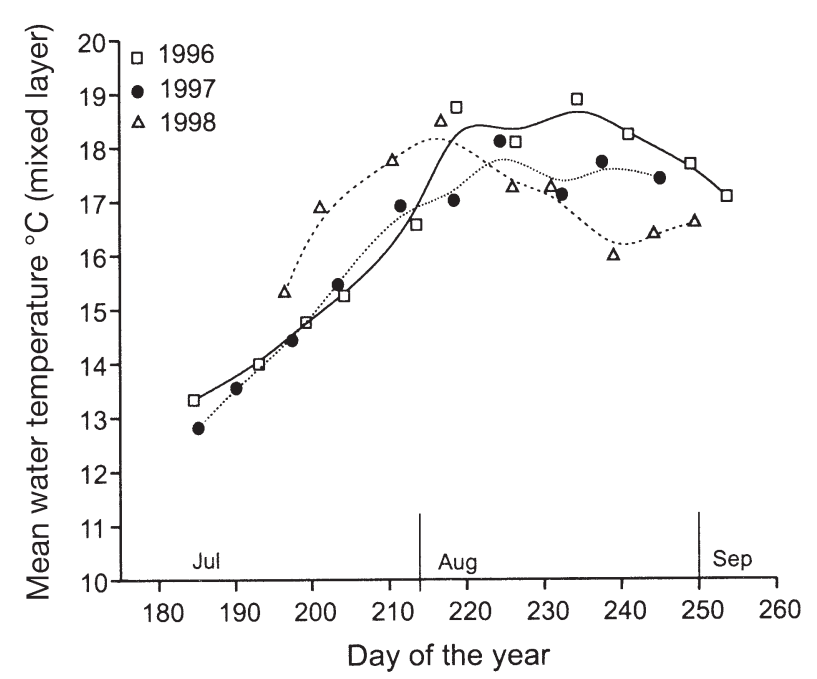

Fig. 2. Weekly mean water temperature in the mixed layer over the survey area for 1996 through 1998

percent increase at the molt (MI\%) was calculated as: [(mean CL stage ${ }_{i+1}$ sampling week $_{i+1}-$ mean CL stage ${ }_{i}$ sampling week $_{i}$ )/mean CL stage $_{i}$ sampling week $_{i}$ ] $\times 100$, where $i=1$ to 4 (larval stages).

The differences in larvae size among areas and years were tested by $t$-test and 1-factor ANOVA analyses. Within each year, ANOVA analyses and a posteriori hypothesis tests were used to test the effect of sampling week on weekly mean CL for all stages (SYSTAT $^{\circledR}$ 1998). For each case, homogeneity of variance was tested with the Bartlett test before running the analyses (Sokal \& Rohlf 1995). No transformation of the data was necessary. Linear regressions were used to test for relationships between MI\% (arcsine transformed) and mean protein growth rate estimates, sampling week, and water temperature. The larvae TAG content (nutritional index) was expressed as the TAG/sterol ratios and TAG/total protein (mg) ratios to account for differential larval size (Fraser 1989, Harding \& Fraser 1999).

\section{RESULTS}

\section{Seasonal temperature pattern}

The same pattern of weekly mean mixed-layer water temperature was observed each year: an increasing trend from the end of June up to the first days of August (up to sampling week 5 or 6 : first period) followed by a second period of warm water (Fig. 2). However, interannual differences were also noted as the mixed layer was warmer in July
1998 relative to 1996 and 1997. Each year, the maximum was recorded in early August but the temperatures for the rest of the month were higher in 1996 relative to 1997 and 1998. In 1998, the weekly mean temperature declined more rapidly following the maximum observed, and by mid-August the water temperature reached the minimum recorded for the 3 yr (Fig. 2).

The rate of temperature change was also compared among years. For the July cruises or up to Day 215 (first period), the daily rate of temperature increase was higher in $1998\left(0.205^{\circ} \mathrm{C} \mathrm{d}^{-1}\right)$ followed by $1996\left(0.161^{\circ} \mathrm{C}\right.$ $\left.\mathrm{d}^{-1}\right)$ and was lowest in $1997\left(0.123^{\circ} \mathrm{C} \mathrm{d}^{-1}\right)$. From the maximum in early August to the end of the sampling season (second period), water temperature remained stable in 1997 but declined by $0.031^{\circ} \mathrm{C} \mathrm{d}^{-1}$ and $0.021^{\circ} \mathrm{C}$ $\mathrm{d}^{-1}$ in 1996 and 1998, respectively.

\section{Spatial heterogeneity in larval size}

For the statistical analyses, the sampling site on the eastern side of the Magdalen Islands was divided into 3 areas: A-southern sector; B-eastern sector, and C-northeastern sector (Fig. 1). Areas A and C were sampled only during the July cruises of each year (and in the first week of August in 1997), while lobster larvae and the post-larval stage were sampled throughout the season in Area B and Baie de Plaisance each year (Table 1).

In July 1996, Stage I and II lobster larvae from Area C were significantly ( $t$-test; $\mathrm{p}<0.05$ ) larger $(\mathrm{CL})$ than larvae from Area B (Table 2). In July 1997, there was no significant difference in CL between the 3 areas for all stages (ANOVA; $\mathrm{p}>0.05$ ) (Table 2). In July 1998, mean CL of Stage I larvae in areas A and C were both significantly (ANOVA and Tukey's a posteriori test; $\mathrm{p}<0.05$ ) larger than Stage I larvae from Area B (Table 2). There was no difference in mean size of Stage II larvae between Areas A and B in 1998.

Table 2. Comparison of lobster larval stages mean carapace length \pm SD (sample size) among areas for the July cruises at the Magdalen Islands from 1996 to 1998. Differences between means were tested with $t$-test statistics or ANOVA with a posteriori Tukey's test at $\mathrm{p}=0.05$

\begin{tabular}{|c|c|c|c|c|}
\hline Year & Stage & Area A & Area B & Area C \\
\hline \multirow[t]{3}{*}{1996} & I & & $1.984 \pm 0.138(866)$ & $<2.014 \pm 0.152(188)$ \\
\hline & II & & $2.736 \pm 0.185(96)$ & $<\quad 2.798 \pm 0.163(48)$ \\
\hline & III & & $3.652 \pm 0.184(20)$ & $=3.696 \pm 0.190(16)$ \\
\hline \multirow[t]{3}{*}{1997} & $\mathrm{I}$ & $1.967 \pm 0.136(68)$ & $=1.961 \pm 0.137(758)$ & $=1.985 \pm 0.135(108)$ \\
\hline & II & $2.713 \pm 0.163(65)$ & $=2.695 \pm 0.171(351)$ & $=2.675 \pm 0.171(59)$ \\
\hline & III & $3.634 \pm 0.291(10)$ & $=3.542 \pm 0.172(99)$ & $=3.539 \pm 0.160(19)$ \\
\hline \multirow[t]{3}{*}{1998} & I & $1.986 \pm 0.122(184)$ & $>\quad 1.914 \pm 0.141(490)$ & $<1.978 \pm 0.160(58)$ \\
\hline & II & $2.755 \pm 0.166(33)$ & $=2.782 \pm 0.138(15)$ & \\
\hline & III & & $3.424 \pm 0.130(6)$ & \\
\hline
\end{tabular}




\section{Seasonal and interannual variability in larval size and growth}

Since seasonal larval sampling was concentrated in Area B each year, temporal patterns and trends in lobster larvae CL were investigated for Area B only. In 1996, a significant temporal heterogeneity was present in Stage I larvae $\mathrm{CL}$, but there was no (negative) linear trend in the weekly mean CL over the season (Table 3, Fig. 3). For Stage II larvae, the analysis revealed no significant effect of the sampling week on mean larval CL (Table 3, Fig. 3). Stage III lobster larvae were rare in 1996 and found in significant numbers during 2 short periods (Fig. 3). However, comparison of mean larval size among weeks revealed that the early Stage III larvae were larger than the late larvae (Table 3). No significant linear trend was detected in lobster postlarvae CL in 1996; however, from sampling week 4 onward, the post-larval stage weekly mean CL declined overtime (Fig. 3). In 1997, a significant sampling week effect, but no negative trend, was detected in weekly mean Stage I CL (Table 3). In Stage II larvae, despite larger CL size early in the season, the tests for linear trend in mean CL were not significant (Table 3 , Fig. 3). Stage III larvae CL significantly decreased with time in 1997 (Table 3, Fig. 3). However, the changes overtime in post-larvae weekly mean CL were not significant (Table 3, Fig. 3). Lastly, in 1998, no effect of the sampling week was detected in Stage I larvae mean CL but a significant negative linear trend was revealed in Stage II larvae CL (Table 3, Fig. 3). As for 1996, early Stage III larvae were larger than late Stage III (Table 3). In addition, in August 1998, post-larvae mean CL significantly declined with time (Table 3, Fig. 3).

Overall, for day of the year $\leq 210$ (first period, Fig. 2) and Area B only, Stage I larvae were larger (ANOVA and a posteriori Tukey's test, $\mathrm{p}<0.05$ ) in $1996 \mathrm{com}-$ pared to 1997 and 1998 when they were the smallest (Table 2). Differences in Stage II CL were not significant among years (Tukey's test, $\mathrm{p}>0.05$ ). However, Stage III larvae in 1996 were larger than in 1997 and 1998, but not significantly different between 1997 and
1996
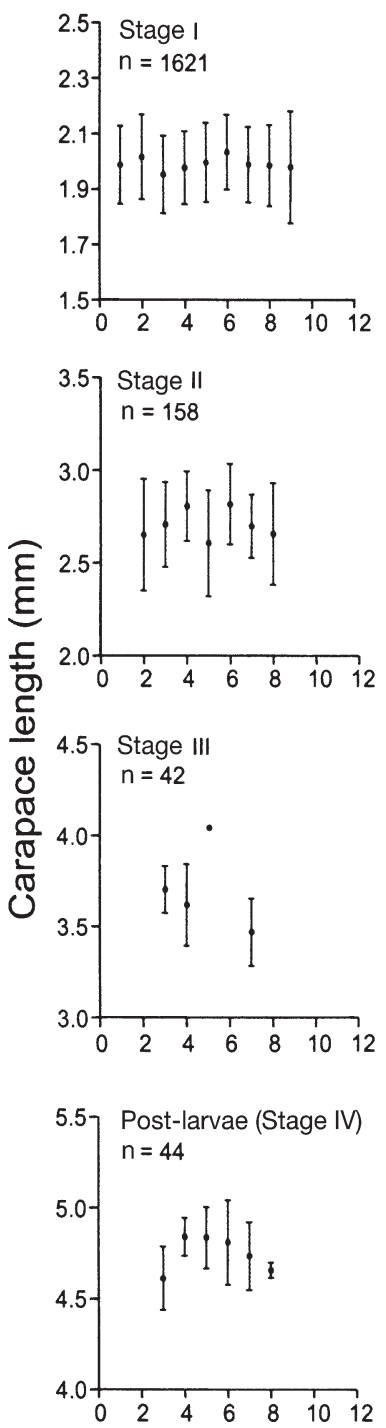

1997
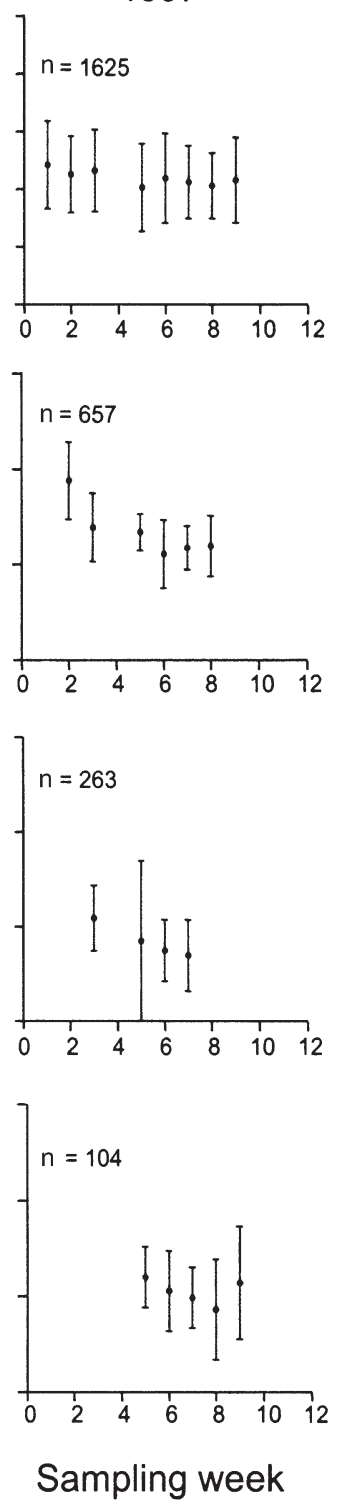

1998
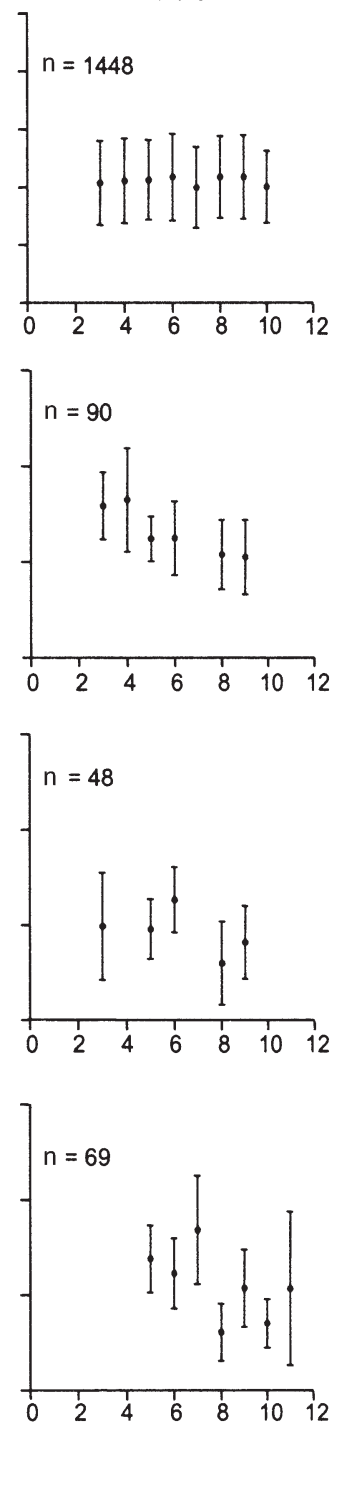

Fig. 3. Illustration of temporal changes in lobster larval and post-larval stages weekly mean $( \pm \mathrm{SD})$ size $(\mathrm{CL})$ for each sampling season: $\mathrm{n}=$ total number of larvae measured for each stage each year

1998 (Tukey's test, $\mathrm{p}>0.05$ ). For days of the year $>210$ (second period, Fig. 2), Stage I and II lobster larvae were still larger in 1996 and there was no difference between 1997 and 1998 (Tukey's test; p < 0.05; Table 4). Stage III larvae were smaller in 1997 compared to 1996 and 1998 (Tukey's test, p < 0.05). For the post-larvae, they were larger in 1996 compare to 1997 and 1998 (Tukey's test, p < 0.05) but not significantly different between 1997 and 1998 (Table 4).

Similar temporal variability in lobster Stage II and III larvae and post-larvae biomass (mg protein ind.$^{-1}$ ) were 
Table 3. Results of the statistical analyses for the effect of sampling week on lobster larvae CL, for each stage and year, and the results of a posteriori tests of a linear effect of sampling week on mean larvae CL (dep. = dependant variable, indep. = independent variable for the single-factor ANOVA). Statistically significant results $(p<0.05)$ in bold. Hypothesis: linear decreases across the ordered means

\begin{tabular}{|c|c|c|c|c|c|c|c|c|c|}
\hline Year & Stage & $\begin{array}{c}\text { ANOVA } \\
\text { dep.-indep. }\end{array}$ & df & $F$ & $\mathrm{p}$ & Hypothesis & df & $F$ & $\mathrm{p}$ \\
\hline \multirow[t]{4}{*}{1996} & I & CL-week & 8 & 5.115 & $<0.001$ & Neg. trend & 1 & 0.011 & 0.918 \\
\hline & II & CL-week & 6 & 1.508 & 0.179 & & & & \\
\hline & III & CL-week & 3 & 6.246 & 0.001 & Neg. trend & 1 & 9.634 & 0.004 \\
\hline & IV & CL-week & 5 & 0.823 & 0.541 & & & & \\
\hline \multirow[t]{4}{*}{1997} & I & CL-week & 7 & 4.427 & $<0.001$ & Neg. trend & 1 & 3.271 & 0.071 \\
\hline & II & CL-week & 5 & 22.035 & $<0.001$ & Neg. trend & 1 & 0.28 & 0.597 \\
\hline & III & CL-week & 3 & 16.948 & $<0.001$ & Neg. trend & 1 & 11.966 & $<0.001$ \\
\hline & IV & CL-week & 4 & 0.848 & 0.498 & & & & \\
\hline \multirow[t]{4}{*}{1998} & I & CL-week & 8 & 1.229 & 0.277 & & & & \\
\hline & II & CL-week & 5 & 2.829 & 0.021 & Neg. trend & 1 & 8.966 & 0.004 \\
\hline & III & CL-week & 4 & 7.676 & 0.001 & Neg. trend & 1 & 1.514 & 0.225 \\
\hline & IV & CL-week & 6 & 4.225 & 0.001 & Neg. trend & 1 & 7.975 & 0.006 \\
\hline
\end{tabular}
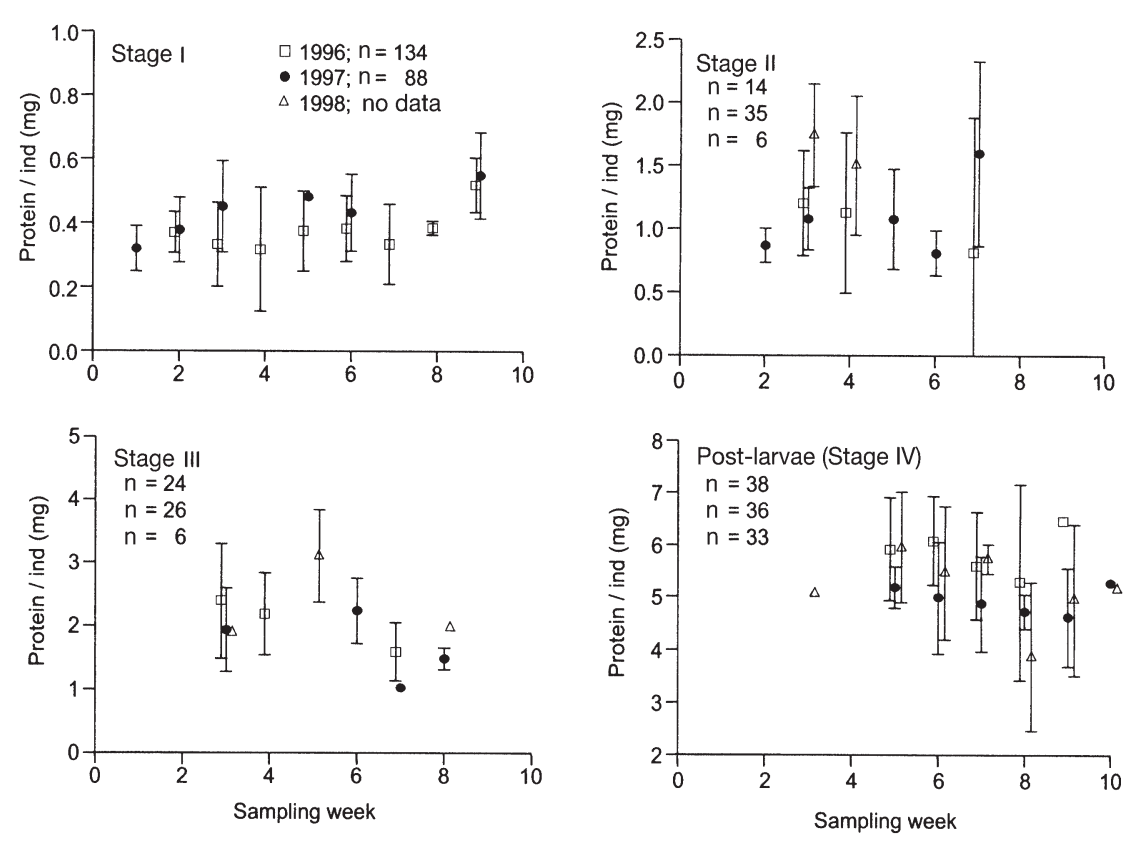

Fig. 4. Weekly mean $( \pm \mathrm{SD})$ lobster larvae and post-larvae biomass as a function of sampling week and comparison among years: $\mathrm{n}=$ total number of larvae analyzed for each stage and each year

Table 4. Comparison of lobster larvae mean CL \pm SD (sample size) for the second sampling period, in Area B only, at the Magdalen Islands from 1996 to 1998. Differences between means were tested with ANOVA with a posteriori Tukey's test at $\mathrm{p}=0.05$

\begin{tabular}{|c|c|c|c|c|}
\hline Stage & 1996 & & 1997 & 1998 \\
\hline I & $1.998 \pm 0.131(680)$ & $>$ & $1.935 \pm 0.143(841)$ & $=1.936 \pm 0.138(841)$ \\
\hline II & $2.694 \pm 0.181(56)$ & $>$ & $2.561 \pm 0.160(296)$ & $=2.588 \pm 0.196(71)$ \\
\hline III & $3.468 \pm 0.180(21)$ & $>$ & $3.355 \pm 0.167(160)$ & $<3.484 \pm 0.240(42)$ \\
\hline IV & $4.764 \pm 0.206(37)$ & $>$ & $4.513 \pm 0.200(104)$ & $<4.568 \pm 0.241(64)$ \\
\hline
\end{tabular}

also observed each year where larvae protein content appeared higher at the beginning of the sampling season, but the trends were not significant $(\mathrm{p}>$ 0.05) due to the low number of larvae available for analysis each week and, consequently, the high variability in the estimates (Fig. 4). However, overall, lobster post-larvae were bigger (mg protein ind..$^{-1}$ ) in 1996 relative to 1997 (ANOVA and a posteriori Tukey's test, $\mathrm{p}<0.05)$ but the differences were not significant ( $p>0.05$ ) between 1996 and 1998 and between 1997 and 1998.

\section{Larvae nutritional condition and growth}

For all larval stages and years, weekly mean TAG/total protein and TAG/sterol ratios were very variable, again because of the low number of larvae analyzed for the weekly estimates, and it is difficult to detect significant seasonal and interannual patterns (Fig. 5). Nevertheless, beginning from sampling week 5, the nutritional condition indices of Stage I lobster larvae appear higher in 1996 than in 1997 (Fig. 5). TAG content decrease in Stage II but the quantity of TAG increase 10fold in the post-larvae relative to the previous stages. The nutritional indices in post-larvae tended to decline with the season in all years; however, the 

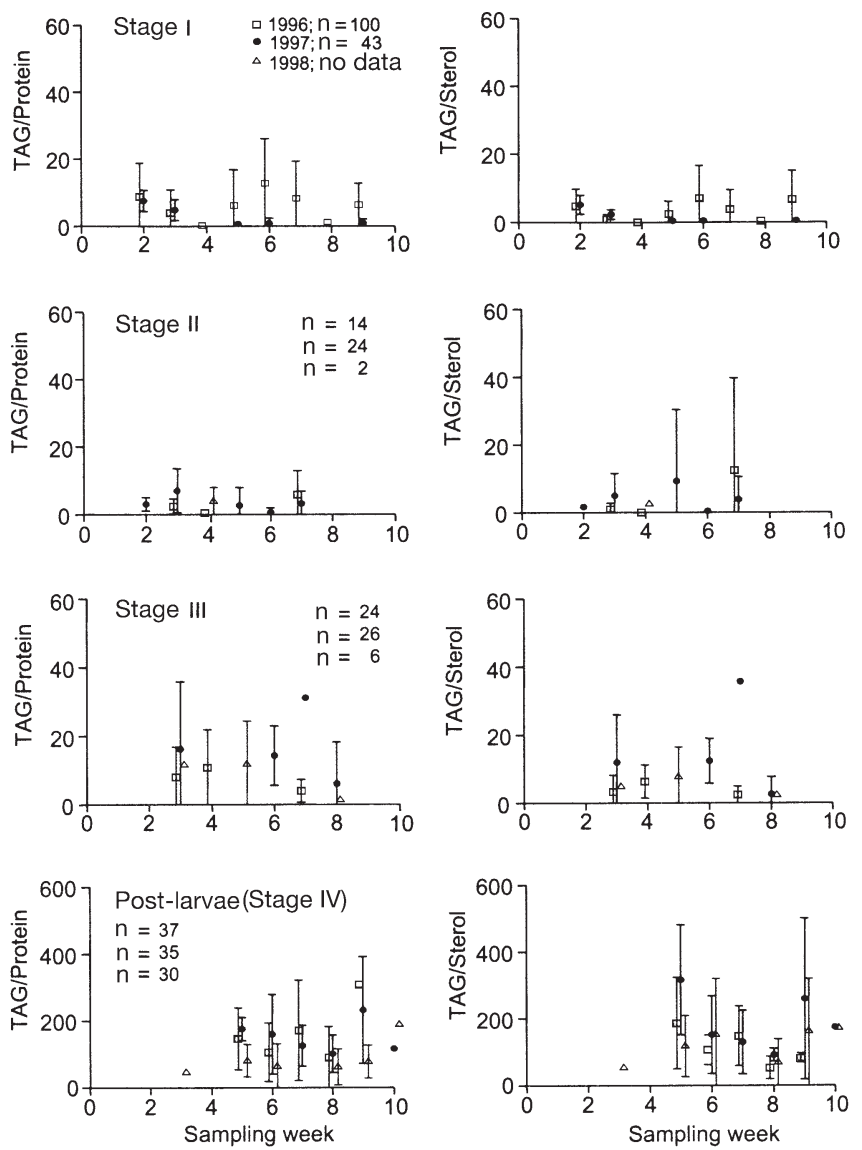

Fig. 5. Weekly mean $( \pm \mathrm{SD})$ lobster larvae and post-larvae nutritional condition indices as a function of sampling week and comparison among years: $\mathrm{n}=$ total number of larvae analyzed for each stage and each year

decline was more pronounced in the TAG/sterol index, while the TAG content relative to post-larvae biomass (TAG/protein ratios) remained more stable (Fig. 5).

For each year, at the first molt, the percent molt increment $(\mathrm{MI} \%)$ decreased overtime and with warmer water temperature (Fig. 6). The regressions were significant with temperature in $1997\left(\mathrm{r}^{2}=0.62, \mathrm{p}=\right.$ $0.04)$ and in $1998\left(r^{2}=0.54, p=0.05\right)$. Overall, it appears, despite some low MI\% values early in 1996, that the early cold water temperature accounted for larger size increase at the first molt (all data: $\mathrm{r}^{2}{ }_{\text {week }}=$ $0.23, \mathrm{p}=0.019$ and $\mathrm{r}_{T}^{2}=0.19, \mathrm{p}=0.037$ ). Despite the general positive relationships observed for 1997 and 1998, the relations between MI\% at the second molt and time or water temperature were not significant $(p>0.05)$, either for each year at a time or for all data combined (Fig. 6). For the third molt, positive trends over time and with temperature were observed each year, but the relations were not statistically significant except for MI\% and week in $1997\left(r^{2}=0.94, p=0.02\right)$. By combining all years, MI\% at the third molt was pos- itively related to water temperature, but the regression was significant $\left(\mathrm{r}^{2}=0.31, \mathrm{p}=0.042\right)$ only after masking the outlier value at $18^{\circ} \mathrm{C}$ (Fig. 6).

In comparison with the larvae CL data, there were relatively few larvae available to estimate protein growth rates from field samples, and that, unfortunately, results in few data points for each year. Indeed, too few for meaningful statistical analysis for each year separately. However, for each molt stage, there was a positive relationship between protein growth rate and sampling week and temperature (Fig. 7). Combining the estimates for all $3 \mathrm{yr}$, the relationships were significant for protein growth rates at the second molt and both sampling week $\left(\mathrm{r}^{2}=0.58, \mathrm{p}=0.048\right)$ and temperature $\left(\mathrm{r}^{2}=0.83, \mathrm{p}=0.007\right)$.

In addition, percent size increase at the molt and protein growth rates were positively correlated for Stage II and III larvae (Pearson linear correlation; $r=$ $0.69 ; \mathrm{p}=0.004$ ), but not for Stage I larvae (Fig. 8). Instead, for Stage I lobster larvae, MI\% was positively related to duration of the stage (i.e. negatively related to water temperature; see Fig. 6).
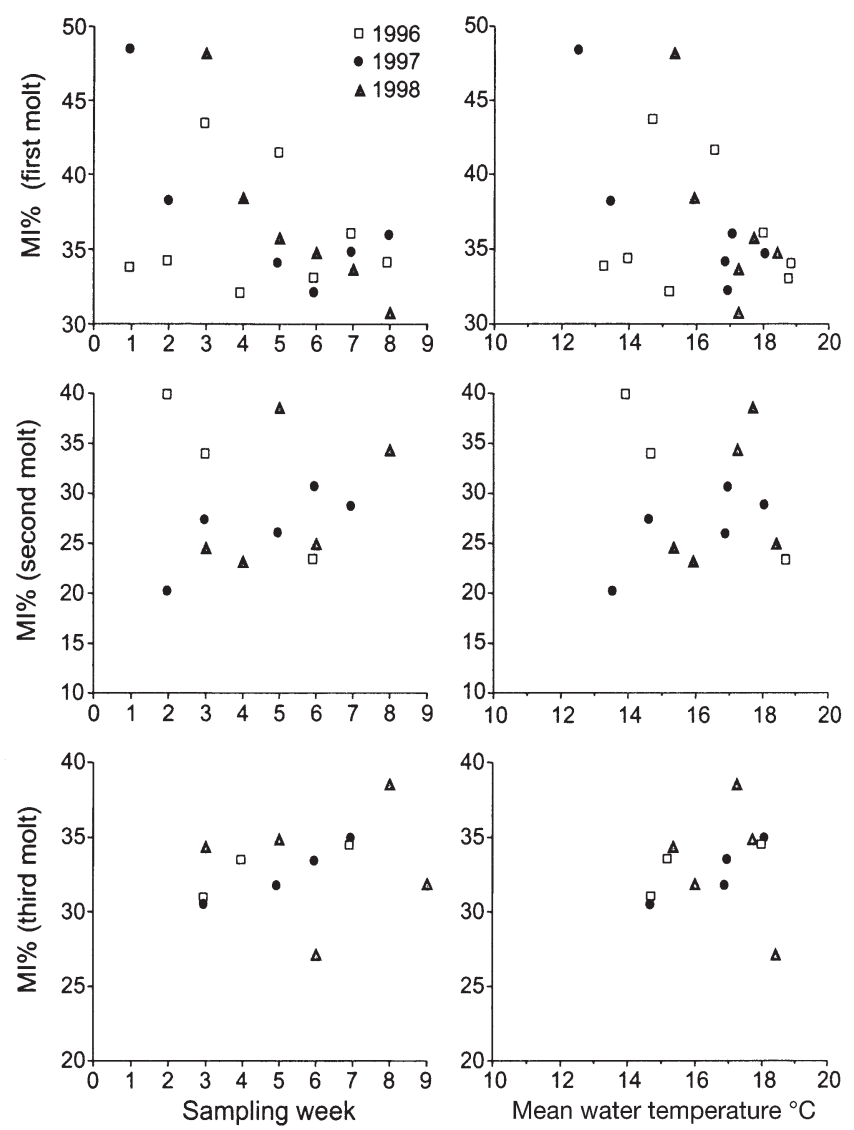

Fig. 6. Seasonal trends in lobster larvae percent size increase at the molt (left panel) and relationships between percent size increase at the molt and water temperature (right panel) for each sampling season 

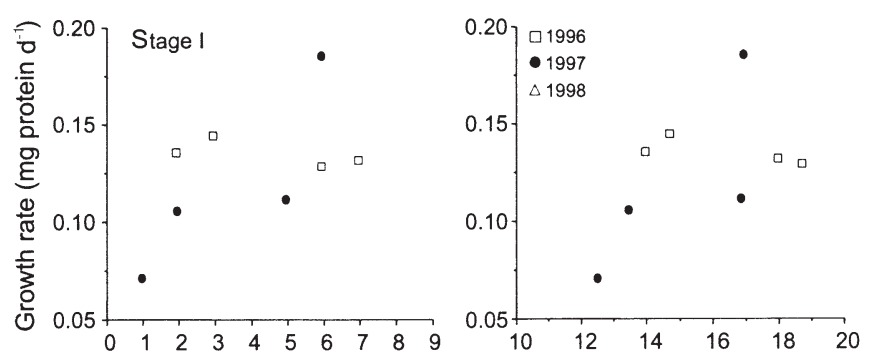

was detected over the season. The estimation of percent molt increment for the first 2 sampling weeks were also much smaller in 1996 relative to the same period in 1997 and 1998.

From the end of July and throughout August, water temperatures remained high and were more stable. The estimated Stage II larvae mean protein growth rates increased with water temperature but shorter stage duration meant that the negative trends persist for the Stage III larvae. Even in 1996, when Stage II CL showed no trend over time, August temperatures were the highest of the $3 \mathrm{yr}$, and late Stage III larvae were smaller than early Stage III larvae. The significant differences in Stage III larvae size during each season are reflected in the post-larvae CL despite the fact that the negative linear trend in CL was significant only in 1998. Protein growth rates during the late planktonic stage (Stage III larvae) appear to influence post-larvae size as much as stage duration. Mean protein growth rates were higher in Stage III larvae and the estimates were positively related to temperature each year. In 1996 and 1997, 2 seasons where water temperature remained warm until September, no significant decline was observed in post-larvae CL during the season. Higher growth rates apparently compensate in part for the negative trends observed in Stage III larvae size. Nevertheless, declining water temperature in late August in 1996 could have been responsible for the diminishing post-larvae CL at the end of the sampling season. In 1998, the important decline in water temperature in mid- and late August may have contributed to the reduction in Stage III protein growth rate and, despite longer stage duration, to the declining size of the post-larvae late that season. The same trends as in larvae CL can be seen in larvae and post-larvae living

\section{Seasonal and interannual variability in larvae and post-larvae size}

Seasonal variability in the mean CL of lobster Stages II and III larvae and post-larval stage seems to result from the synergetic effect of protein growth rates and duration of the molt stage under the control of water temperature. Each year, Stage I larvae CL showed relatively little temporal variability and no (negative) linear trend during the season. However, declining percent size increases at the first molt, following the warming of the water column, were responsible for smaller Stage II larvae mean CL late in the season in 1997 and 1998. Moreover, in 1998, the pattern of change in Stage II larvae CL showed a significant negative linear trend over time. An increasing trend in protein growth rates with warmer temperature was apparently insufficient to compensate for the shorter duration of the stage. In 1996, Stage II larvae mean CL was high in mid-season and no significant linear trend

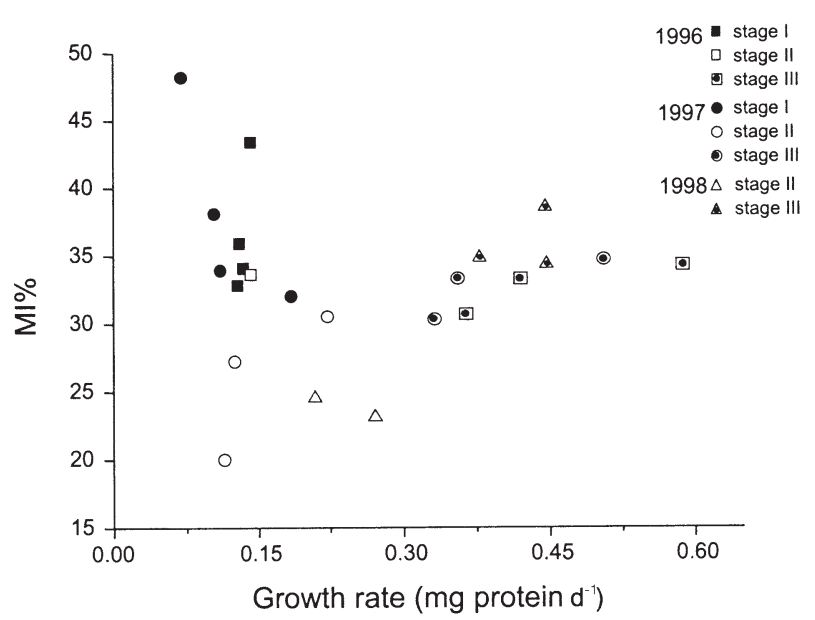

Fig. 8. Relationships between percent size increase at the molt and protein growth rates for each larval stage and year of study 
biomass (total protein per individual) each season. In addition, for the post-larvae, the negative slope, albeit non significant, was more pronounced in 1998 relative to 1997 and 1996. Overall, lobster post-larvae were also bigger in 1996, the year of warmer temperatures in August.

However, the initial difference in Stage I larvae CL among areas and years cannot be attributed to the effect of water temperature during larval development. Hypothetically, the spatial and interannual differences may be the result of different size structure of reproductive females among areas and years (Templeman 1948). In a recent investigation of the effect of lobster female size (CL) on the characteristics of the larvae (Plante 2001), a relationship was observed between female size and the size of hatching Stage I larvae. The adult lobster population is spatially structured around the Magdalen archipelago. Proportionally more large lobsters are found toward the northeast sector (Area C) and smaller adult lobsters are more frequent in the southeast sector (Area B) (Axelsen \& Dubé 1978). The larger Stage I larvae observed in Area A in July 1998 may represent larvae hatched from large females on the north side of the Islands that drifted in a southeasterly direction. Moreover, for interannual comparison, analysis of fishery monitoring data revealed that large female lobster (>90 mm) accounted for $11 \%$ of the reproductive population in early summer 1996 compared to only 4 and $8 \%$ in 1997 and 1998, respectively (Louise Gendron, Fisheries and Oceans Canada, Maurice Lamontagne Institute, pers. comm.).

The spatial heterogeneity in Stage I larvae CL may represent a difficulty for the interpretation of the observed seasonal changes in lobster larval mean sizes each year. Indeed, the possibility exists that the inconsistent results recorded for $\mathrm{MI} \%$ at the first molt in 1996 may originate from the mixing of larvae of different areas (e.g. larger Stage I larvae from Area C into Area B) early in the sampling season. However, although an earlier investigation suggested that the southeast sector (Baie de Plaisance) receives larvae from the northeast (Hudon et al. 1986), the dynamics of larval drift and mixing around the Islands is still poorly known. In addition, when considering Stage I larvae from Area B only there was no systematic changes in mean CL over time each year. That should indicate that we were able to monitor continuous emergence and seasonal growth in lobster larval stages in the southeast sector without much interference from larvae from other areas.

Estimations of decapod larvae in situ growth rates are not common. Incze et al. (1984) used a similar approach to estimate mean growth rates of crab Chionoecetes bairdi and C. opilio larvae from field samples. Intermolt growth rates (dry wt $\mathrm{d}^{-1}$ ) were estimated by comparing mean dry weight of early and late molt stage Zoeae I and II after correction for the effect of formaldehyde on the samples. In our study, mean CL size should not have been affected, as can be larval weight, by preservation in formaldehyde solution. In addition, the changes in size can also be observed when comparing the fresh biomass (total protein) of the larval stages. Instead, the limits of these methods, despite intensive sampling effort, are more in the low number of data points that it is possible to obtain for any given year. The growth rates derived must also be seen as average values dependent on correct estimates of stage duration from available environmental data, and under the assumption that the same larval population was monitored through time. However, lobster larvae were sampled with a high temporal intensity for $3 \mathrm{yr}$, and all the patterns described were consistent among years, which gives confidence to the interpretation of the results despite the shortcomings of the data (few data points, high variability) for the statistical analyses.

\section{Larvae nutritional condition and growth}

Lobster larvae nutritional condition indices were based on the TAG and sterol content of the hepatopancreas as it is recognized that this organ is the center for lipid storage and metabolism even in larval decapods (O'Connor \& Gilbert 1968, Chang \& O'Connor 1983, Anger 1998, Jeffs et al. 2001). Even after logarithmic transformation, the TAG/total protein and TAG/sterol ratios for the Stages I and II larvae were higher around the Magdalen Islands in comparison with values reported recently for lobster larvae on the George Bank, Gulf of Maine, region (Harding \& Fraser 1999). The ratios for the Stage III larvae and the post-larvae are more similar for the 2 studies. Most specimens used for biochemical analysis were at intermolt Stage $\mathrm{C}$ or $\mathrm{D}_{0}$, when the premolt organic energy reserves are accumulated (Anger 1987, Ouellet et al. 1992). Moreover, Harding \& Fraser (1999) presented evidence that TAG continue to increase throughout the intermolt and premolt periods; hence, the TAG ratios presented here should be considered as minimal values, which would indicate good nutritional condition and, probably, no food-limited growth for lobster early stages at Magdalen in each year of this study. Using the critical 0.1 TAG/sterol ratio (after logarithmic transformation) of Harding \& Fraser (1999), 30 and $20 \%$ of Stage I larvae had low condition indices in 1996 and 1997, respectively (no data for Stage I in 1998), but less than $5 \%$ of Stages II and III and $0 \%$ of the post-larvae had low condition indices each year. However, by using only the hepatopancreas and not the entire lobster, the 
quantity of sterol was less in our sample, and there may be the possibility of inflated TAG/sterol ratios relative to Harding \& Fraser's study. The effect will be less for the Stage III larvae and, particularly, for the post-larvae due to the very large and highly variable quantity of TAG at those stages (see also Harding \& Fraser 1999). Nutritional condition was also assessed as TAG content relative to larvae biomass (total protein), and there were no appearance of interannual differences in the larvae condition. Interestingly, the post-larvae TAG ratios increased at the end of each season (see Fig. 3). It seems that late season post-larvae accumulated more reserve lipids before settlement at the bottom.

Any estimation of decapod larvae size and nutritional condition from quantification of biochemical components will be sensitive to the position of the specimens on the molt cycle (especially for condition index based on hepatopancreas lipids only). However, most larval biomass is accumulated during the first third of the molt cycle, i.e. postmolt and early intermolt stages (Anger 1998). In American lobster larvae, although the maximum in protein as mg per individual was reached in early premolt, the rate of protein accumulation was much lower past the $\mathrm{D}_{0}$ intermolt stage (Sasaki 1984). Moreover, the temporal increase in nitrogen (a proxy for total protein) content was also minimal in comparison with dry weight changes during the molt cycle in Norway lobster Nephrops norvegicus larvae (Anger \& Püschel 1986). In this study, of all lobster larvae used for the biochemical analyses in 1997, between $60 \%$ (Stage III larvae) and $95 \%$ (Stage I larvae) of the specimens were at intermolt Stage $\mathrm{C}$ or $\mathrm{D}_{0}$. In 1998, the proportions varied between $50 \%$ (Stage III larvae) and $100 \%$ (Stage II larvae). Therefore, the estimates of total protein and lipid content should be comparable between years for each larval stage. Unfortunately, the molt stage information was not recorded in 1996.

\section{Significance of larvae and post-larvae size variability}

The previous estimates of lobster larvae size and growth from the Magdalen Islands were made in the late 1970s/early 1980s (Hudon \& Fradette 1988). Overall, the estimated mean CL for each lobster planktonic stage are similar to those reported earlier, but the differences in mean size observed among areas were not found during the previous study. The difference could be that the spatial coverage and sampling intensity were much higher relative to the last investigation (Hudon et al. 1986). However, the seasonal change in Stage III larvae and post-larvae CL has been reported before (Hudon \& Fradette 1988). These authors then hypothesized that the declining size of lobster postlarvae during the season reflects the early disappearance from the plankton of the larger and faster growing individuals. Instead, the results suggest that the acceleration of development at higher temperature was responsible for smaller planktonic lobster larvae despite the fact that (protein) growth rates are positively influenced by temperature. The results are more in agreement with Templeman's (1948) hypothesis that lower water temperature is associated with larger molt increment and that lobster larvae are smaller at warmer temperatures. The evidence presented suggests also that, under conditions of limited variability in temperature, lobster post-larvae size can be influenced by the growth rates of the third molt stage. In this study, lobster post-larvae varied by 10 and $20 \%$ in CL and biomass, respectively, within a given season.

Although timing of settlement was more important, the combination of post-larvae size and timing of settlement explained $40 \%$ of the variability in lobster size and instar attained only a few months after settlement (James-Pirri et al. 1998). This initial heterogeneity in size, and its consequence in the growth trajectory of young lobsters, may have profound implications for the recruitment and population dynamics of lobster populations (Sheehy et al. 1999). Three years of investigation of lobster larvae at the Magdalen Islands suggests that lobster size variability may originate during the conditions for growth and development of the larval stages. Development of a full growth model of lobster larvae and post-larvae stages, incorporating initial size, food limitations, and temperature could become a precious tool in the estimation of settlement and recruitment success and abundance in lobster populations.

Acknowledgements. We are very thankful to all ship personnel that contributed to the many cruises on board the 'F.G. Creed' and 'Navicula', and also to Guy Jean for his help in keeping the small boats in operation. We also acknowledge the skill of Daniel Beaulieu in the design and the manufacture of the sampling gears. Thanks also to Jonathan Tardif, Céline Duluc and all the team members of the lobster research program at the Magdalen Islands between 1996 and 1998. Many thanks to Drs Gareth Harding, Bernard Sainte-Marie and Jeffrey Runge, and to 3 anonymous referees for their comments and suggestions on an earlier version of the manuscript. This is a contribution to the Canadian Lobster Atlantic-Wide Studies (CLAWS) initiative of Fisheries and Oceans Canada.

\section{LITERATURE CITED}

Anger K (1987) The $\mathrm{D}_{0}$ threshold: a critical point in the larval development of decapod crustaceans. J Exp Mar Biol Ecol 108:15-30

Anger K (1998) Patterns of growth and chemical composition in decapod crustacean larvae. Invertebr Reprod Dev 33: 159-176

Anger K, Püschel C (1986) Growth and exuviation of Norway 
lobster (Nephrops norvegicus) larvae reared in the laboratory. Ophelia 25:157-167

Axelsen F, Dubé P (1978) Etude comparative du homard (Homarus americanus) des différentes regions de pêches des Îles de la Madeleine. Ministère de l'Industrie et du Commerce. Direction générale des Pêches Maritimes. Cahiers d'Information, No. 86 (in French)

Chang ES, O'Connor JD (1983) Metabolism and transport of carbohydrates and lipids. In: Mantel LH (ed) The biology of Crustacea, Vol 5. Academic Press, New York, p 263-287

Ennis G (1995) Larval and postlarval ecology. In: Factor JR (ed) Biology of the lobster. Academic Press, New York, p 23-46

Fraser AJ (1989) Triacylglycerol content as a condition index for fish, bivalve, and crustacean larvae. Can J Fish Aquat Sci 46:1868-1873

Harding GC, Fraser AJ (1999) Application of the triacylglycerol/sterol condition index to the interpretation of larval lobster Homarus americanus distribution in close proximity to Georges Bank, Gulf of Maine. Mar Ecol Prog Ser 186:239-254

Harding GC, Pringle JD, Vass WP, Pearre S Jr, Smith SJ (1987) Vertical distribution and daily movements of larval lobsters Homarus americanus over Browns Bank, Nova Scotia. Mar Ecol Prog Ser 41:29-41

Hudon C, Fradette P (1988) Planktonic growth of larval lobster (Homarus americanus) off îles de la Madeleine (Québec), Gulf of St. Lawrence. Can J Fish Aquat Sci 45: 868-878

Hudon C, Fradette P, Legendre P (1986) La répartition horizontale et verticale des larves de homard (Homarus americanus) autour des îles de la Madeleine, golfe du SaintLaurent. Can J Fish Aquat Sci 43:2164-2176 (in French)

Incze LS, Wencker DL, Armstrong DA (1984) Growth and average growth rates of Tanner crab zoeae collected from the plankton. Mar Biol 84:93-100

James-Pirri MJ, Cobb JS, Wahle RA (1998) Influence of settlement time and size on postsettlement growth in the American lobster (Homarus americanus). Can J Fish Aquat Sci 55:2436-2446

Jeffs AG, Nichols PD, Bruce MP (2001) Lipid reserves used by pueruli of the spiny lobster Jasus edwardsii in crossing the continental shelf of New Zealand. Comp Biochem Physiol A 129:305-311

MacKenzie BR (1988) Assessment of temperature effects on

Editorial responsibility: Otto Kinne (Editor),

Oldendorf/Luhe, Germany interrelationships between stage durations, mortality, and growth in laboratory-reared Homarus americanus Milne Edwards. J Exp Mar Biol Ecol 116:87-98

O'Connor JD, Gilbert LI (1968) Aspects of lipid metabolism in crustaceans. Am Zool 8:529-539

Ouellet P, Taggart CT, Frank KT (1992) Lipid condition and survival in shrimp (Pandalus borealis) larvae. Can J Fish Aquat Sci 49:368-378

Ouellet P, Lefaivre D, Allard JP (2001) Lobster (Homarus americanus) larvae abundance and post-larvae availability to settlement at the Magdalen Islands, southern Gulf of St. Lawrence (Quebec). In: Tremblay MJ, Sainte-Marie B (eds) Canadian Lobster Atlantic-Wide Studies (CLAWS) Symposium: abstracts and proceedings summary. Can Tech Rep Fish Aquat Sci 2328

Plante F (2001) Influence de la taille des femelles sur la taille et la croissance des larves de homard (Homarus americanus). MSc thesis, Université du Québec à Rimouski, p 78

Sasaki GC (1984) Biochemical changes associated with embryonic and larval development in the American lobster Homarus americanus Milne Edwards. PhD thesis (WHOI-84-8), Massachusetts Institute of Technology, Cambridge, and Woods Hole Oceanographic Institution, Woods Hole

Scarratt DJ (1973) Abundance, survival, and vertical and diurnal distribution of lobster larvae in Northumberland Strait, 1962-63, and their relationships with commercial stocks. J Fish Res Board Can 30:1819-1824

Sheehy MRJ, Bannister RCA, Wickins JF, Shelton PMJ (1999) New perspectives on the growth and longevity of the European lobster (Homarus americanus). Can J Fish Aquat Sci 56:1904-1915

Somero GN, Childress JJ (1990) Scaling of ATP-supplying enzymes, myofibrillar proteins and buffering capacity in fish muscle: relationship to locomotory habit. J Exp Biol 149:319-333

Sokal RR, Rohlf FJ (1995) Biometry, 3rd edn. WH Freeman and Co, New York

SYSTAT $^{\circledR}$ (1998). SPSS Inc, Chicago, IL

Templeman W (1936) The influence of temperature, salinity, light and food conditions on the survival and growth of the larvae of the lobster (Homarus americanus). J Biol Board Can 2:485-497

Templeman W (1948) Growth per molt in the American lobster. Bull Newfoundland Gov Lab 18:26-48

Submitted: February 26, 2001; Accepted: September 20, 2001

Proofs received from author(s): March 12, 2002 